\title{
The effectiveness of using biological preparations in the production technology for seed material of potatoes
}

\author{
Maya Orzaliyeva ${ }^{1}$, Yelena Didanova ${ }^{1}$, Timur Zherukov ${ }^{1}$, Khusen Nazranov ${ }^{1, *}$, and Akrom \\ Ishnazarov $^{2}$ \\ ${ }^{1}$ Kabardino-Balkarian State Agricultural University named after V.M. Kokov, Lenin Avenue, 1V, \\ 360030 Nalchik, Russia \\ ${ }^{2}$ Tashkent State University of Economics, Islam Karimov Str., 49, 100066 Tashkent, Republic of \\ Uzbekistan
}

\begin{abstract}
An integrated plant protection system must focus on the biologization of this process. Used phytohormones and phytofungicides have a biostimulating and fungicidal effect on potato plants. The biological products used to one degree or another increase the adaptogenic capabilities of plants. Biological preparations have provided a high level of immunity of potato plants to major diseases. The fungicidal properties of the preparations were well appeared. No increase in infection or spread was observed in experiments using biofungicides. To a greater extent, the preparations acted as prophylactic ones, preventing the penetration of the phytopathogen into plants. At the same time, there is a long period of suppression of its development, the formation of resistance to late blight. The immunostimulating effect of Zircon and Epin extra in relation to late blight is found to a lesser extent in comparison with the Trichodermin, Rizoplan and Baktofit biofungicides. The fungicidal action of these preparations proved to be highly effective.
\end{abstract}

\section{Introduction}

An integrated plant protection system must focus on the biologization of this process. "It stands out from traditional methods, first of all, by the biocenotic approach, taking into account not individual species, but faunistic complexes of interconnected organs, the relationship between which can significantly affect the number of harmful organisms" [1].

As G. I. Bazdyrev puts it: "The model of an integrated plant protection system is: the use of methods for agrotechnical prevention and suppression of harmful objects; the use of techniques that preserve and promote the development of entomophages; sowing crops only with resistant varieties that are zoned in a given territory; application of methods for active suppression of harmfulness of harmful objects (autocidal method, biological and chemical plant protection products), taking into account the forecast of the development of harmful objects and economic thresholds of pests, diseases and weeds harmfulness "[1].

\footnotetext{
* Corresponding author: nazranov777@mail.ru
} 
Taking into account the current policy trend for the use of chemicals and the greening of agricultural production, with the fact that the use of a chemical control method has significant consequences, it is necessary to increase the use of scientifically substantiated organizational, agronomic, biological methods. The complex use of various control methods allows the optimal way to protect crops from diseases, pests and weeds, and at the same time minimize the harmful effects on the environment $[1,4,5,6,9]$.

You can eliminate unwanted results by searching for environmentally friendly methods of plant protection. Actually, the problem of environmental protection determines the development of non-chemical methods for plant protection, namely biological methods.

The problem of solving the task, providing the population of the southern region of the country with ecologically safe agricultural products is the most important at the present stage of development of the region and country agro-industrial complex.

The main task in the field of development, regulations for the use of growth regulators and their optimization is the problem of finding functional phytoregulators and inducers of plant resistance to diseases and pests, which could provide stimulation of potato growth and development. At the same time, it is important to note that great importance is attached to improving the quality indicators of products and their technological characteristics. $[2,5,6,8]$.

Obtaining high-quality seed material is an urgent issue for every agricultural manufacturer. The yield and quality of products mainly depend on this.

The purpose of this work is to optimize the technological parameters of the use of biological preparations for the production of potato seed material in the mountainous zone of the KBR.

The scientific novelty lies in the identification of the fundamental possibility of using biological preparations to protect potatoes from pests and diseases, as well as for the general stimulation of crop growth.

The practical significance of the work lies in the greening of the production of potato planting material by using biological methods in an integrated crop protection system.

\section{Materials and Methods}

Research work to identify the effectiveness of plant growth regulators is carried out as part of the plan for a comprehensive scientific and technical project "Production of high-quality seed potatoes of competitive domestic varieties in a virus-free environment of the mountainous zone of the Kabardino-Balkarian Republic" in the fields of LLC "Zolsky Potato".

The cultivation technique in the potato seed multiplication nursery-garden is designed for using advanced technology with the application of high quality tools and machines. During investigations for planting, super elite seed tubers of a domestic variety with an average weight of $65 \mathrm{~g}$ were used. Winter barley was the predecessor in the crop rotation. The planting scheme provided for the distribution of 60 thousand tubers per hectare, the planting depth was $10-15 \mathrm{~cm}$, when creating the ridge, its height was $18-20 \mathrm{~cm}$. The working area of the plot is $72 \mathrm{~m}^{2}$, the accounting area is $60 \mathrm{~m}^{2}$.

Taking into account the large number of studied physiologically active substances (PAS) and various methods of their use on potatoes, depending on the tasks to be solved, specific schemes for the use of growth regulators and microbiological preparations were laid.

Field experiments, observations, laboratory analyzes were carried out according to generally accepted methods. Mathematical processing of the yield was carried out using computer programs for statistical data processing. 
During the growing season of potatoes, observations, analyzes, and accountance were carried out in accordance with generally accepted methods. Phenological observations were carried out in accordance with the "Research Methods for the Potato Culture" [3].

Cleaning is performed manually.

Registration procedures for diseases are carried out without fail: late blight, ring rot, black leg, common scab, rhizoctonia and viral diseases. For all varieties of the same ripening period, the level of starch content in potato tubers is determined.

The tasting is carried out by groups of varieties ripeness twice.

The assimilation surface area was determined using a modified technique for accelerated calculation of the leaf surface area for agricultural crops using a scanner.

The potato crop structure analysis; the resistance of plants to diseases and pests was assessed before harvesting according to the "Standard scale for taking into account the damage to the surface of tubers by diseases" (Anisimov B.V., 2001) [4].

The quality indicators of the yield were determined by its content of dry matter - starch, nitrogen, ash content, and the content of vitamins. The dry matter yield in tubers was determined by drying at a temperature of $105^{\circ} \mathrm{C}$, starch - by washing and further drying the crushed mass of tubers, nitrate nitrogen - using the $\mathrm{pH}$ meter by an electrode method, protein - according to GOST 134964-84. ash content - found on the tubers burned in a muffle furnace, previously well washed, dried and weighed (according to GOST 26226-84), was determined on a Parov scales according to the method described in the tutorial on plant growing. Mathematical processing of the varieties yield was carried out by the variance analysis method on a computer [7].

\section{Experimental design}

The scheme of the use of biological products (table 1) consisted of processing tubers before planting and three times processing of tops in the phase of full germination, budding and after the flowering phase.

Table 1. Scheme of processing potato crops with biological preparations.

\begin{tabular}{|c|c|c|c|c|c|}
\hline Option & $\begin{array}{c}\text { Seed } \\
\text { processing }\end{array}$ & $\begin{array}{c}\text { Full } \\
\text { germinati } \\
\text { on phase }\end{array}$ & $\begin{array}{l}\text { Budding } \\
\text { phase }\end{array}$ & $\begin{array}{c}\text { Flowering } \\
\text { phase }\end{array}$ & $\begin{array}{c}\text { Remar } \\
\text { ks }\end{array}$ \\
\hline I. Control (water) & - & - & - & & \\
\hline II.Zircon & $\begin{array}{c}0.5 \text { мл } / 1 \text { per } 8 \\
\mathrm{~h}\end{array}$ & $0.35 \mathrm{ml} / 1$ & $0.35 \mathrm{ml} / 1$ & $\begin{array}{c}0.5 \text { мл } \\
\text { After } \\
\text { flowering }\end{array}$ & $\begin{array}{c}3501 / \mathrm{h} \\
\mathrm{a}\end{array}$ \\
\hline III. Epin extra & $\begin{array}{l}1 \mathrm{Ml} / 250 \mathrm{ml} \\
\text { of water }, 3 \\
\text { hours }\end{array}$ & $60 \mathrm{ml} / \mathrm{ha}$ & $60 \mathrm{ml} / \mathrm{ha}$ & $\begin{array}{c}60 \mathrm{ml} / \mathrm{ha} \text {, } \\
\text { beginning } \\
\text { of } \\
\text { flowering }\end{array}$ & $\begin{array}{c}3501 / h \\
\mathrm{a}\end{array}$ \\
\hline IV. Trichodermin & $\begin{array}{c}200 \mathrm{ml} / 10 \mathrm{ml} \\
\text { of water, } 2-3 \\
\text { min }\end{array}$ & $1.5 \mathrm{~kg} / \mathrm{ha}$ & $2.8 \mathrm{~kg} / \mathrm{ha}$ & $2.8 \mathrm{~kg} / \mathrm{ha}$ & $\begin{array}{c}3501 / h \\
\mathrm{a}\end{array}$ \\
\hline V. Rizoplan & $\begin{array}{c}101 / 1 \text { ton of } \\
\text { tubers }\end{array}$ & - & 101/ha & $101 / \mathrm{ha}$ & $\begin{array}{c}3501 / h \\
\mathrm{a}\end{array}$ \\
\hline VI. Baktofit & $\begin{array}{c}1 \mathrm{ml} / 500 \mathrm{ml} \text { of } \\
\text { water }\end{array}$ & $350 \mathrm{ml} / \mathrm{ha}$ & $700 \mathrm{ml} / \mathrm{ha}$ & $700 \mathrm{ml} / \mathrm{ha}$ & $\begin{array}{c}3501 / h \\
\mathrm{a}\end{array}$ \\
\hline
\end{tabular}

\section{Results and Discussion}

The results obtained during the investigations to determine the effectiveness of the use of growth regulators on potatoes indicate an increase in the utilization rate of photosynthetically active radiation. In the control variant, this index was at the level of $1.29 \%$. The use of phytoregulators of growth according to the recommended technology 
increased the utilization rate of FAR for phytohormones Zircon and Espin extra by 0.08 and $0.03 \%$, respectively (table 2 ).

Table 2. Productivity index of potato early variety Zhukovsky.

\begin{tabular}{|l|c|c|c|c|c|}
\hline \multicolumn{1}{|c|}{ Option } & $\begin{array}{c}\text { Leaf } \\
\text { surface } \\
\text { area, thous. } \\
\mathrm{m}^{2} / \mathrm{ha}\end{array}$ & $\begin{array}{c}\text { Dry } \\
\text { biomass } \\
\text { yield, } \\
\text { t/ha }\end{array}$ & $\begin{array}{c}\text { The } \\
\text { productivity } \\
\text { of the leaves } \\
\text { (PRL) or the } \\
\text { output of } \\
\text { marketable } \\
\text { products per } \\
\text { 1 thousand } \\
\text { units of FP, } \\
\text { kg of tubers }\end{array}$ & $\begin{array}{c}\text { Net } \\
\text { productivi } \\
\text { ty of } \\
\text { photosynt } \\
\text { hesis } \\
\text { (NPF), } \\
\text { g/m² day }\end{array}$ & $\begin{array}{c}\text { FAR } \\
\text { utilization } \\
\text { factor,\% }\end{array}$ \\
\hline $\begin{array}{l}\text { I. control } \\
\text { II.Zircon }\end{array}$ & 39.3 & 7.166 & 9.2 & 3.84 & 1.29 \\
\hline $\begin{array}{l}\text { III. Epin } \\
\text { extra }\end{array}$ & 43.5 & 7.988 & 10.3 & 4.18 & 1.37 \\
\hline $\begin{array}{l}\text { IV. } \\
\text { Trichodermin }\end{array}$ & 43.1 & 7.845 & 10.1 & 4.08 & 1.32 \\
\hline V. Rizoplan & 42.8 & 7.857 & 9.8 & 4.00 & 1.30 \\
\hline VI. Baktofit & 43.7 & 7.864 & 9.9 & 4.07 & 1.35 \\
\hline
\end{tabular}

The analysis of biometric indexes shows that the use of phytoregulators of growth and phytofungicides causes an increase in plant height by an average of $8.9 \mathrm{~cm}$, and in terms of the number of stems, the first two options are higher by $0.7 \mathrm{pcs} / \mathrm{bush}$. This suggests that the process of growth and development of the aboveground part of potato plants, which assimilates organic matter, is more productive on options with the use of Zircon and Epin extra phytohormones. Their net productivity of photosynthesis is higher, and this suggests that the yield on these options shall be higher, which was confirmed by the results of harvesting potatoes. The number of tubers increased in all variants of the use of biological products in comparison with the standard plant protection system in the technology of growing potatoes in this natural climatic zone.

Thus, the use of biological products in the technology of growing potatoes, in the system of integrated plant protection has a positive effect: the rate of growth processes, the duration of the period of photosithetically active radiation, stimulate the main metabolic processes, and increase the quantitative indexes of productivity parameters. Ultimately, all this causes the formation of a higher productivity of potato plants.

The analysis of the productivity results of Nart variety potatoes (table 3 ) showed that with the use of biological products, the percentage of standard products output significantly increases, this index was $10 \%$ higher than the control option. On the option with Epin extra, the number of tubers is greater than on all options, while the average weight of tubers from one bush is high - $631 \mathrm{~g} / \mathrm{bush}$. On this option, the average tuber weight is the lowest, which indicates the unevenness of the tuber laying. That is, in a bush of plants there is a large weight of medium tubers, the most suitable as seed material.

Table 3. Potato yield depending on the use of various biological preparations.

\begin{tabular}{|c|c|c|c|c|c|c|}
\hline \multirow{2}{*}{$\begin{array}{l}\text { Experimental } \\
\text { option }\end{array}$} & \multicolumn{3}{|c|}{ Replication, $\mathrm{t} / \mathrm{ha}$} & \multirow{2}{*}{$\begin{array}{c}\text { Average } \\
\text { biological } \\
\text { yield by } \\
\text { experimental } \\
\text { options, t/ha }\end{array}$} & \multirow{2}{*}{$\begin{array}{c}\text { Standard } \\
\text { products, } \%\end{array}$} & \multirow{2}{*}{$\begin{array}{c}\text { Raise, } \\
\%\end{array}$} \\
\hline & 1 & 2 & 3 & & & \\
\hline
\end{tabular}


Table 3. Continued.

\begin{tabular}{|c|c|c|c|c|c|c|}
\hline I. control & 18.2 & 19.3 & 19.2 & 18.9 & 85.7 & - \\
\hline II.Zircon & 22.0 & 21.1 & 20.8 & 21.3 & 95.1 & 12.7 \\
\hline III. Epin extra & 21.2 & 21.8 & 20.3 & 21.1 & 85.4 & 11.6 \\
\hline $\begin{array}{c}\text { IV. } \\
\text { Trichodermin }\end{array}$ & 18.6 & 20.3 & 20.2 & 19.7 & 95.9 & 4.2 \\
\hline V. Rizoplan & 20.6 & 19.8 & 20.2 & 20.2 & 94.6 & 6.8 \\
\hline VI. Baktofit & 20.1 & 18.9 & 20.7 & 19.9 & 96.9 & 5.3 \\
\hline NSR0.5 & 0.4888 & 0.5444 & 0.4455 & 0.49 & & \\
\hline
\end{tabular}

Our investigation results were subjected to economic analysis, as a result of which it is possible to more accurately judge the effectiveness of a particular technique studied in the experiment.

For the analysis, we used the data of the main economic indexes of the economy in which the investigation was conducted. Economic analysis data are represented in Table 4.

Table 4. Economic efficiency of using biological preparations on potatoes.

\begin{tabular}{|c|c|c|c|c|c|c|}
\hline & \multicolumn{5}{|c|}{ Crops } \\
\cline { 2 - 7 } Indicators & control & Zircon & $\begin{array}{c}\text { Epin } \\
\text { extra }\end{array}$ & $\begin{array}{c}\text { Tricho } \\
\text { dermi } \\
\mathrm{n}\end{array}$ & $\begin{array}{c}\text { Rizo } \\
\text { plan }\end{array}$ & Baktofit \\
\hline $\begin{array}{c}\text { Yield of } \\
\text { standard } \\
\text { tubers, t/ha }\end{array}$ & 16.2 & 20.3 & 18.1 & 18.9 & 19.1 & 19.3 \\
\hline $\begin{array}{c}\text { Direct costs of } \\
\text { production, } \\
\text { thousand } \\
\text { rubles }\end{array}$ & 105.3 & 118.5 & 119.2 & 118.9 & $\begin{array}{c}118 . \\
4\end{array}$ & 118.4 \\
\hline $\begin{array}{c}\text { Price for 1 ton } \\
\text { of young tuber, } \\
\text { thousand } \\
\text { rubles. }\end{array}$ & 25 & 25 & 25 & 25 & 25 & 25 \\
\hline $\begin{array}{c}\text { Gross cost, } \\
\text { thousand } \\
\text { rubles. }\end{array}$ & 405 & 507.5 & 452.5 & 472.5 & 477. & 5 \\
\hline $\begin{array}{c}\text { Net income, } \\
\text { thousand } \\
\text { rubles }\end{array}$ & 299.7 & 389.0 & 333.3 & 353.6 & 359. & 364.1 \\
\hline $\begin{array}{c}\text { Net cost, } \\
\text { thousand } \\
\text { rubles/ton }\end{array}$ & 6.5 & 5.8 & 6.5 & 6.3 & 6.2 & 6.1 \\
\hline $\begin{array}{c}\text { Profitability } \\
\text { level, \% }\end{array}$ & 284.6 & 328.3 & 279.6 & 297.4 & 303. & 307.5 \\
\hline
\end{tabular}

They show that the Nart variety is responsive to the use of biological preparations in potato growing technology to obtain a young tuber. Biological preparations, both phytohormones and phytofungicides, increased productivity. This was especially clearly appeared when using Zircon, the yield of standard tubers exceeded the control option by 4.1 $\mathrm{t} / \mathrm{ha}$. The use of phytofungicides causes an increase in productivity by an average of 2.9 $\mathrm{t} / \mathrm{ha}$. The conditional net income for the Nart variety with the use of the biological preparation Zircon was 389 thousand rubles/ha, while the level of profitability was $328.3 \%$. 
The net cost of production for this option is 5.8 thousand rubles/ton, which is 0.7 thousand rubles/ton less than the control option.

\section{Conclusions}

Conclusions based on the results of investigations to optimize the regulations for the use of biological preparations in potato growing technology.

Processing of seed tubers and during the growing season with biological preparations gives a positive effect, while the effectiveness using the phytohormones Zircon and Epin extra has higher rates in the formation of an assimilation surface than when using phytofungicides. The use of the biological preparation Zircon increases the area to 44.5 thousand $\mathrm{m}^{2} /$ ha, the productivity of leaf work (PLW) or the yield of marketable products per 1 thousand units of FP $10.3 \mathrm{~kg}$ of tubers, with a net productivity of photosynthesis $4.18 \mathrm{~g} / \mathrm{m}^{2}$ day.

The highest dry matter content in tubers was observed in the options with the use of the Epin extra and Trehodermin biological preparation, the maximum value for this index was $26.8 \%$. A higher starch content was noted for the use options of phytohormone and Baktofit $16.1 \%$, which is $5.9 \%$ higher than the control option. The use of biological preparations increases the quality indexes of commercial products in terms of dry matter content by 0.3 $0.6 \%$, and the starch content by $0.6-0.9 \%$.

The use of the phytohormone Zircon in the cultivation technology provided 20.3-20.8 ton/ha of potato tubers of the Nart variety, with a marketable output of $95.1 \%$.

When carrying out a general phytopathological assessment of the variety, only late blight was recorded among the diseases.

The low degree of infestation is primarily due to high-quality seed material and the choice of a site in the crop rotation. The use of biofungicides completely restrained the development of late blight, and the percentage of prevalence in other options is insignificant.

So, on the basis of the investigations carried out, the following conclusions can be drawn: the treatment of seed tubers of the Nart variety potatoes with biological products contributes to obtaining a larger assimilation surface and an increase in the duration of its work. The processes of development, an increase in the number of stems, bushiness, plant height, and the number of tubers in a bush are accelerated.

Used phytohormones and phytofungicides have a biostimulating and fungicidal effect on potato plants. The biological products used to one degree or another increase the adaptogenic capabilities of plants. Biological preparations have provided a high level of immunity of potato plants to major diseases. The fungicidal properties of the preparations were well appeared. No increase in infection or spread was observed in experiments using biofungicides. To a greater extent, the preparations acted as prophylactic ones, preventing the penetration of the phytopathogen into plants. At the same time, there is a long period of suppression of its development, the formation of resistance to late blight. The immunostimulating effect of Zircon and Epin extra in relation to late blight is found to a lesser extent in comparison with the Trichodermin, Rizoplan and Baktofit biofungicides. The fungicidal action of these preparations proved to be highly effective.

So, a systematic analysis of experience shows a high level of effectiveness of biological preparations.

The economic efficiency of using biological fertilizers, biostimulants and the biological method in the integrated plant protection system for growing potatoes is very high and amounts to more than $300 \%$. 


\section{References}

1. G. I. Bazdyrev, N. N. Tretyakov, O. O. Beloshapkina, Integrated protection of plants against harmful organisms (2014)

2. H. M. Nazranov, A. K. Yezaov, Ye. N. Didanova, et al., Intensive technology for the production of organic vegetable products (2019)

3. B. A. Dospekhov, Field experiment technique (1985)

4. A. I. Anisimov, O. V. Smirnov, S. A. Dobrokhotov, Agricultural news, 2, 33-36 (2009)

5. I. V. Andreyeva, M. V. Shternshis, O. G. Tomilova, Biological plant protection (2018)

6. S. S. Litvinov, Method of field experiment in vegetable growing (2011)

7. A. K. Akhatov and others, Diseases and pests of vegetables and potatoes (2013)

8. S. A. Bekuzarova, I. M. Haniyeva, L. S. Gishkayeva, Ecological Consequences of Incre asing Crop Productivity: Plant Breeding and Biotic Diversity, 23-27 (2014)

9. M. M. Shakhmurzov, A. S. Gordeev, V. V. Kulintsev, Y. A. Yuldashbaev, N. V. Konik, R. A. Ulimbasheva, M. B. Ulimbashev, South of Russia: Ecology, development, 3, 8395 (2018) 